\title{
Pineapple farmer corporation development strategy in Central Lampung District, Indonesia
}

\author{
Noor Roufiq Ahmadi ${ }^{*}$, Maesti Mardiharini ${ }^{2}$, and Chandra Indrawanto ${ }^{2}$ \\ ${ }^{1}$ Indonesian Center for Horticulture Research and Development, Jl. Tentara Pelajar No. 3C \\ Cimanggu, Kecamatan Bogor Barat, Kota Bogor, Jawa Barat \\ ${ }^{2}$ Indonesian Center for Agricultural Technology Assessment and Development, \\ Jalan Tentara Pelajar No.10 Cimanggu, Kecamatan Bogor Barat, Kota Bogor, Jawa Barat Indonesia
}

\begin{abstract}
Central Lampung is a pineapple production center that supplies fresh pineapples for national demand. On the other hand, Suboptimal production and marketing, which are still controlled by middlemen, are the main problems in pineapple development. The research aims to identify the potential and needs for innovation, and to formulate a strategy for developing pineapple based on farmer cooperations. The research was conducted from September 2020 in Punggur District, Lampung. Data collection was carried out through a Focus Group Discussion (FGD) and in-depth interviews with local champions. The SWOT approach as well as IFE and EFE analysis have been determine to the best strategy. The results showed that farmers used the Queen variety from 1970, so that, the quality production decreased. The innovations needed are mainly related to cultivation (irrigation, crop rotation, control of pests). The existence of Farmer-Owned Enterprises in collaboration with BUMDES has the potential to be reactivated into a farmer corporation. The IFE and EFE analysis showed that the strategy that needs to be taken is the development strategy (SO strategy). Therefor, Policies that need to be followed is increasing: The role and skills of extension workers; and the role of farmers group or corporation in pineapple production and marketing.
\end{abstract}

\section{Introduction}

Pineapple (Ananas Comocus (L). Merr) is one of the horticultural products that has high economic value and regarded as one of the leading commodity in Indonesia. This refers to the total production of the fruit pineapple is high in Indonesia to 4 after fruit banana, mango and citrus, with production reaching 2.196.456 tons in the year 2019 [1]. Pineapple export from Indonesia has penetrated to more than 75 countries in 2019, with the main destination to various countries in Europe, America, and Asia. Export market and demand in country is still widely opened, so that it becomes a challenge to increase the production of pineapple. The Spreading of pineapple plant in Indonesia is almost equally distributed throughout the region, because the region of Indonesia has a diversity of agro-climate which allows the development of various types of plants, either tropical hotricultural or subtropical

* Corresponding author: noorroufiq@pertanian.go.id 
holticultural plants. The largest province of Pineapple producer is Lampung with $32.8 \%$ of the total national production. Then it followed by West Java with $11.4 \%$, North Sumatra $10.9 \%$, as well as Central java and East Java respectively $8 \%$ [2].

Pineapple production in Lampung is dominated by the Central Lampung Regency, with the contribution of the production reaches $99.7 \%$ in 2019. PT. Great Giant Pineapple (PT GGP) one of the companies under Gunung Sewu Group, has the big role as the factory in processing pineapple in the district and controlling more than 33 thousand hectares of land to produce pineapple. Types of pineapple planted is Smooth Cayenne, superior type and it is very good and special type, because it has no spines in skin to ease the processing. PT. GGP is also listed as a third largest factory which processing canned pineapples in the world. This company does not sell its products in country, all products are produced on export to foreign countries, $40 \%$ of them to Europe, $35 \%$ in North America and the other $25 \%$ to the Asia Pacific. Farmers are the segment of the production of pineapple in Central Lampung Regency, which is less than one percent also require attention, because the type of pineapple planted also the typical ones to meet domestic demand. The less optimum production and middlemen's control to the marketing, are the main problems in the growtht of the pineapple in this region [3].

The formation of the corporate farming is one of the efforts to optimize the value added and competitiveness of the product that developed in a region. The agricultural zones development which based on coorporate farming is accordance with the mandate in Regulation of Agriculture Ministry No. 18/2018, that is aimed to combine a series of plans and implementation of policies, programs, activities and budget of the construction of agriculture areas; and encouraging the empowerment of farmers in an economic institution of the farmers in the area defined as the area of agriculture in order to become a complete unity in the perspective of the farming system. Farmer-based corporate agricultural zones development target include: (a) increasing the production, productivity, value added and competitiveness of the commodity priorities of the national agricultural; (b) the availability of support infrastructure and agriculture in the agricultural optimally; (c) achieving the innovative technology specific location in agricultural zones; (d) increasing the knowledge, skills and entrepreneurship of farmers in managing institutional peasant economy; and (e) the proper functioning of the farming system as a whole, effective and efficient. The target is measured through the increasing of real incomes in farm households, the scale of the Farming Business, the margin of profit to the farmer, and the formation of the differentiation and downstream products.

The corporate farming development is also one of the development goals that has been set out in the RPJMN 2020-2024. Through the corporate, it is expected that farmers and businesses can be more independent, they can manage their own business in the form of cooperatives or limited company (PT). so far, the profit, in particular in marketing the product more be traders and collectors. The formation of corporate farming need big capital to businesses, so in the implementation, its cooperating with the Bank and other business partners [4].

Supporting policy above, then the best production of pineapple in both quantity and quality should be maintained so that the sustainability and independence of the program can be guaranteed. Innovation for these commodities from upstream to downstream become important to be applied at the farm level. Identify the supporting and inhibiting factors that come from inside and from the outside are the first steps in strategically planning an agricultural zone [5], or it is also the next step after determining the goals of the organization [6]. Such factors need to be well mixed to formulate the development strategy of the region. Therefore, the intention of this study is to formulate development strategy of pineapple corporate farming in Central Lampung Regency based on the analysis of internal and external factors. This research is expected tobe a reference for policy makers 
both at the central and local levels in the preparing the program of development of pineapple corporate farming in Central Lampung Regency.

\section{Methods}

The survey was performed between September and December 2020, in Central Lampung Regency, Lampung Province. The secondary data used in this study were collected from the Directorate General of Horticulture and the Office of Food Crops and Horticulture in Lampung Province and Central Lampung Regency. Meanwhile, primary data to identify SWOT attributes was carried out through a Focus Group Discussion (FGD) which attended by several stakeholders in the development of pineapple farmer corporations in Central Lampung Regency, including representatives from private sectors, farmers, central and local governments, and Agricultural Extension Office.

The first part of approach of the study focused on the issues of regional development strategies. The approach in this study uses a SWOT analysis as an analytical tool to develop a farmer's corporate area. They were several studies that used SWOT as an analytical tool to identify regional development strategies $[5,7,8,9]$. There are some limitations and shortcomings in the SWOT analysis, such as bias that may arise, does not take into account competitors and several others. Although SWOT analysis has several drawbacks, the SWOT approach is a situation analysis tool that can help policy makers and stakeholders to make initial steps of analysis based on resources and capabilities [6].

The first part of process on SWOT analysis through focus group discussion (FGD) by requesting all stakeholders to write down as many attributes as possible of the internal factors, strengths and weaknesses, as well as external factors, opportunities and threats, which are written on a metaplan paper that has been provided. Furthermore, the metaplan paper is attached to the flipchart paper which is placed on the wall, so that all stakeholders know the attributes that have been written. Through discussion, these attributes are eliminated and grouped based on their similarity. If there are new attributes that arise from the discussion then these attributes will be added to each factor. The final result of the FGD is a several of attributes of each of the factors of strengths, weaknesses, opportunities and threats that have been agreed upon by the stakeholders.

The next step is to quantify the weight and score of each of the identified attributes. The weighting is done by filling out a pairwise comparison questionnaire so that each attribute weights will be obtained which will total 1 . The scoring is done using a likert scale (1-4) questionnaire to express approval of each attribute. The quantification results will be explained in the Internal Factors Evaluation (IFE) and External Factors Evaluation (EFE) matrixes which will show which of the internal and external factors are the most dominant $[10,5]$. Based on the above process, the position of Central Lampung Regency will be identified in the internal-external matrix (IE) to determine the development strategy decision-making steps. This matrix will be divided into three regions, namely areas that include cells I, II, and IV, namely the grow and build position with an appropriate strategy, namely an intensive strategy, an area that includes cells III, V, VII, namely the hold and maintain position with a penetration strategy. market and product development, as well as areas covering cells VI, VIII, IX, namely the position of harvest and divest [10].

The results of the IFE and EFE matrices will be a meeting point that determines the position of Central Lampung Regency in the IE matrix. The next step is to create a strategic position and action evaluation (SPACE) matrix and a SWOT matrix. [5] uses the SPACE matrix to recommend strategic priorities from several alternatives generated by the SWOT matrix, namely strategic priorities to seize opportunities using strengths (SO), minimize weaknesses with opportunities (WO), use strengths to minimize threats (ST), and how to overcome weaknesses that pose a threat (WT). 
Tabel 1. IFE and EFE matrix

\begin{tabular}{|c|c|c|c|c|}
\hline No & $\begin{array}{c}\begin{array}{c}\text { Internal / eksternal factors } \\
\text { attributes }\end{array} \\
\text { (Strenght/opportunity) }\end{array}$ & Weight & Score & Weight $x$ score \\
\hline 1 & 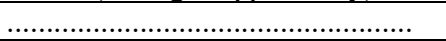 & Weight 1 & Score 1 & Weight $\mathrm{x}$ score 1 \\
\hline 2 & 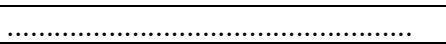 & Weight 2 & Score 2 & Weight $\mathrm{x}$ score 2 \\
\hline . & & & & \\
\hline $\mathrm{n}$ & & Weight $\mathrm{n}$ & Score $n$ & Weight $\mathrm{x}$ score $\mathrm{n}$ \\
\hline & Subtotal of Strenght/opportunity & 1 & & $\mathrm{a}$ \\
\hline & (Weakness/threat) & & & \\
\hline 1 & 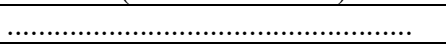 & Weight 1 & Score 1 & Weight $\mathrm{x}$ score 1 \\
\hline 2 & 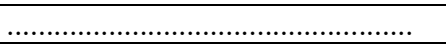 & Weight 2 & Score 2 & Weight $\mathrm{x}$ score 2 \\
\hline . & & & . & \\
\hline$\dot{n}$ & & Weight $\mathrm{n}$ & Score $n$ & Weight $\mathrm{x}$ score $\mathrm{n}$ \\
\hline & Subtotal of Weakness/threat & 1 & & $\mathrm{~b}$ \\
\hline \multicolumn{4}{|c|}{ Total IFE/EFE } & $a+b$ \\
\hline
\end{tabular}

\section{Results and discussion}

\subsection{The characteristics of the region}

Central Lampung regency is located around $58 \mathrm{~km}$ from the city of Bandar Lampung, the capital city of Gunung Sugih and has a land area about a 4,.9 thousand $\mathrm{km}^{2}$. The district is located at $104^{\circ} 35^{\prime}-104^{\circ} 50^{\prime}$ 'East Longitude and $4^{\circ} 30^{\prime}-4^{\circ} 15^{\prime}$ 'South Latitude. The boundary of the region includes the northern border with Kabupaten Tulang Bawang Lampung and North Lampung, the southside borders on Pesawaran District, east Lampung Regency East and Metro City, the westside borfers on the District Tanggamus and Wes Lampung.

Central Lampung Regency consists of 28 Districts and 314 of the village. As one of the largest regencies in the Province of Lampung, it has 1,28 million total population in 2019 (BPS Kabupaten Lampung, 2020). The composition according to the gender of $51.6 \%$ male and $48.4 \%$ female. The rate of population growth is relatively lower, than $0.93 \% / y e a r$ in 2010 , becoming $0.73 \%$ year in 2019. The main livelihood of inhabitants is agricultural sector. According to Utomo (2014) under the results of the analysis klassen typology, namely the fast growing and moving is Central Lampung Regency,the fast developing area is Tanggamus and Pringsewu Regency, the advanced but depressed area is North Lampung and Kabupaten Tulang bawang, Kabupaten Mesuji and the City of Bandar Lampung and underdeveloped areas is are West Lampung, South Lampung East Lampung, Kabupaten Way Kanan, Pesawaran, Tulang Bawang Barat Regency and Metro City. The agricultural sector and industrial processing gives the positive effect on economic growth sector of kabupaten Lampung Tengah in 2011-2017 [11].

Width of land in Central Lampung Regency around 80,8 thousand hectares, while the area surrounding fields is 62.8 thousand hectares. This regency needs to develop and increase the productivity and quality of the various potential natural resources to maintain the food availability. Despite of rice, cassava is one of the leading commodities. Thus, also vegetables and fruits, plantation crops such as sugar cane (sugar), palm oil, and animal husbandry and fisheries, generally sufficient enough, even it tends to surplus in production. Leading commodity of Kabupaten Lampung Tengah represent horticultura sub-sector is pineapple, which is planted in the land dry (fields). The presence of PT.GGP in this district 
is utilizing approximately 33 thousand hectares of fields for canned pineaple pineapple in industry.

\subsection{Potential and constraints to pineapple development in Punggur District, Central Lampung Regency}

Potential of Pineapple Production. Central Lampung Regency is one of the main food production area in Lampung Province, especially in Punggur sub-District. There are 3,779hectare agriculture land in Punggur, mainly as paddy fields around 3,138 hectares and other as dry land. The farmers are groped into 114 farmer groups. Dry land is planting horticultural commodities, such as pineapples, bananas, vegetable crops, and sweet corn. Pineapple is the main commodity, which is spread across 5 villages, namely: Mojopahit, Astomulyo, Mestirahayu, Sidomulyo and Totok Katong, in area of 450 hectares. Pineapple farmers in Punggur Subdistrict on average cultivated of $0.25-0.5$ hectares of farming land. Pineapple production patterns are carried out continuously throughout the year.

The variety of pineapple planted is namely Queen, which was planted in Punggur District since the 60-70s. The variety of queen was a local variety that originally brought by farmers from outside the region, then it has grown to this day. Based on the genetic tracing conducted by the Lampung University, Queen pineapples in Punggur have different genetics from the current Queen pineapples, so they are called Queen Punggur pineapples. Queen Punggur pineapple has a sweet taste with a lower water content compare than Queen Subang pineapple. The shape of the fruit tapers upwards, and It is not suitable for the canned pineapple industry.

Existing Technology and Development Opportunities. Most of the farmers use seeds from their own product. In Punggur sub-district there are some farmers as a seed producer. They produce two type of Queen Punggur pineapple seeds, namely Siwilan and Sogolan. Siwilan seeds come from fruit shoots, with a leaf size of $20-25 \mathrm{~cm}$. The selling price of seedlings is IDR 250/stem and can be harvested two years after planting. The use of siwilan seeds is possible for intercropping with other crops (maize). Sogolan seeds come from shoots of stems, with leaf sizes of 40-50 cm. The selling price of seeds is IDR 500/stem and can be harvested one year after planting. For every hectare of farming activity, the farmers use 40,000 seedlings. The existing Punggur pineapple cultivation stages are:
a) Land sprayed with herbicides (usually using Gramaxon);
b) After the plant dried, the farmers burned it;
c) Land tillage through plowing and trenching
d) Planting with a spacing of $100 \times 25 \mathrm{~cm}$
e) Fertilization and maintenance process phase 1
f) Spraying ZPT for synchronous fertilization
g) Fertilization and maintenance process phase 2
h) Harvesting 
Table 2. Existing and introduced pineapple technology based on cultivation process in Central Lampung, 2020

\begin{tabular}{|c|l|l|l|}
\hline No. & \multicolumn{1}{|c|}{$\begin{array}{c}\text { The Process of } \\
\text { cultivation }\end{array}$} & Technology existing & \multicolumn{1}{|c|}{ Technology Introduction } \\
\hline 1. & Land preparation & Mechanization & $\begin{array}{l}\text { Mechanization + New } \\
\text { Technology }\end{array}$ \\
\hline 2. & Seed & Own seed & Certificate Seed \\
\hline 3. & Planting & Manual & Mechanization \\
\hline 4. & Fertilization & Manual & Special Device \\
\hline 5. & $\begin{array}{l}\text { Maintenance and irrigation } \\
\text { system }\end{array}$ & Manual & Manual/ sprinkle \\
\hline 6. & Pest management & Sprinkle & Machinery \\
\hline
\end{tabular}

The farmers use tractor for land preparation, need plowing twice before ready to use. The cost of plowing is carried out in bulk, for an area of one hectare the cost of plowing was Rp. 380,000, -. Furthermore, the wholesale cost for trenching is Rp. 100.000, - for $1 / 4$ ha. Planting was carried out at a spacing of $100 \times 25 \mathrm{~cm}$. For planting, it is usually carried out by female workers. The cost of female workers is Rp. 35,000, - (works from 07.00 11.00). Fertilize using compost and manure. For $1 / 4$ ha, 50 bags of manure are needed (40 kg wet weight, or $25 \mathrm{~kg}$ dry weight at a price of IDR 20,000/bag); followed by application of inorganic fertilizers, namely Urea 2.5 quintals and Ponska 1.5 quintals. The first use of fertilize at Pineapples are 7-8 months old. The fertilization application that is usually done by farmers is by giving carbide or spraying with protepon. After 35 days, the pineapples will grow fruit shoots and 4-5 months later the pineapples can be harvested.

Pineapple production is a crop that depend on the availability of water, especially from July to November (dry season) the growth of plantations is hampered. So far, farmers have relied more on rainwater, therefore the pineapple growth is not optimal. The production costs incurred by farmers for pineapple cultivation with an area of 0.25 ha are:

Year $1=$ IDR 10,000,000 $\rightarrow$ Year $2=$ IDR 5,000,000 $\rightarrow$ Year $3=$ IDR 5,000,000

Farmers harvest pineapples in the following way: 2 months before harvesting the farmers stop use pesticides. Pineapple is one of fruit with less pesticide residues. Pineapples picked with a yellow tinge; they have a shelf life of 15 days to be ready for consumption. Meanwhile, pineapples harvested at optimal maturity have a shelf life of 7 days.

Marketing Pattern. The marketing of the pineapple harvest is carried out by retail (grain) and / or on a wholesale basis by middlemen. For the wholesale method, usually $1 / 4$ ha of land is priced between 15-25 million rupiah, depending on the size of the fruit. However, if the farmers are lack of capital at planting time, they usually borrow from neighbours and/or collectors, using the planting stock system and returning it at harvest time ("yarnen") with a profit-sharing system. The selling price of pineapples is based on grade, where at harvest time on a weekday the price is standard, while before the fasting month the price is relatively expensive. During the fasting month, many traders compete to get the pineapple. Farmers pile their crops in front of the house, and the collector traders will take them to the farmer's house. Pineapple traders come from Liwa, Jakarta, Tanjungkarang and Tanggamus. In the month of fasting, the selling price reaches 3-4 times. Farmers and collecting traders do grading in marketing pineapple products. There are three grades (A, B, C) based on the size or weight of the fruit, with the following price ranges (Table 3 ). 
Table 3. Pineapple grades and prices in Central Lampung, 2020

\begin{tabular}{|l|c|c|}
\hline \multicolumn{1}{|c|}{ Grade } & Standar Price (Rp) & The Price at fasting time (Rp) \\
\hline $\mathrm{A}=1 \mathrm{~kg} / \mathrm{each}$ & 3.500 & $4.000-6.000$ \\
\hline $\mathrm{B}= \pm 0,75 \mathrm{~kg} / \mathrm{each}$ & 2.000 & 4.000 \\
\hline $\mathrm{C}=<0,75 \mathrm{~kg} / \mathrm{each}$ & 800 & 2.000 \\
\hline
\end{tabular}

Currently there are 12 farmers who have Prima 2 certificates and 200 farmers have registered their gardens. However, due to marketing process is still through collectors, the registration and prime certificates have not been renewed and have no impact on the pineapple price. Farmers said that they would really do registration and certificate of prime even organic if there was market certainty.

The pineapple trade system chain in Punggur is as follows:

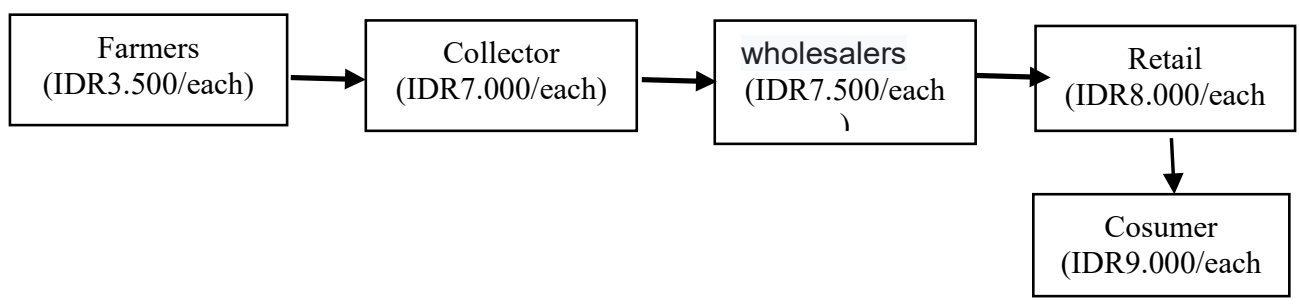

Table 4. Cost Structure of pineapple farming per hectare in Punggur District, Lampung Province, 2020

\begin{tabular}{|c|c|c|c|c|}
\hline No. & Items & Volume & Price (IDR) & Total (IDR) \\
\hline \multirow[t]{21}{*}{ A. } & Input Production, Year-1 & & & \\
\hline & 1. Seed & & & \\
\hline & - $\quad$ Siwilan (tree) & 20.000 & 250 & 5.000 .000 \\
\hline & - $\quad$ Sogolan (tree) & 20.000 & 500 & 10.000 .000 \\
\hline & 2. Fertilizer $(\mathrm{kg})$ & & & \\
\hline & - Manure & 200 & 20.000 & 4.000 .000 \\
\hline & - Urea & 1.000 & 1.800 & 1.800 .000 \\
\hline & - TSP & 600 & 3.500 & 2.100 .000 \\
\hline & - Ponska & 550 & 7.500 & 4.125 .000 \\
\hline & - ZPT & 9 & 35.000 & 315.000 \\
\hline & 3. Pesticide & & & \\
\hline & - $\quad$ Gramoxone (lt) & 7 & 40.000 & 280.000 \\
\hline & 4. Labor & & & \\
\hline & - Tractor dan Ditch & & & 1.920 .000 \\
\hline & $\begin{array}{l}\text { Family Labor (preparation, } \\
\text { Harvest and unload) }\end{array}$ & 2.300 & 50.000 & 57.500 .000 \\
\hline & 5. Land rent (hectare) & 1 & 20.000 .000 & 20.000 .000 \\
\hline & Farm Cost & & & \\
\hline & a. Year-1 (full input) & & & 164.540 .000 \\
\hline & b. Year-2 (Labor only) & & & 22.000 .000 \\
\hline & c. Year-3 (Labor only) & & & 20.000 .000 \\
\hline & Total Farm cost in one period & & & 206.540 .000 \\
\hline B. & Revenue in one period & & & \\
\hline & 1. Grade A $(\geq 1 \mathrm{~kg} / \mathrm{each})$ & 60.500 & 3.500 & 211.750 .000 \\
\hline & $\begin{array}{l}\text { 2. Grade B }(0,5-0,99 \\
\mathrm{kg} / \mathrm{each})\end{array}$ & 38.500 & 2.000 & 77.000 .000 \\
\hline & 3. Grade $\mathrm{C}(<0,5 \mathrm{~kg} / \mathrm{each})$ & 11.000 & 800 & 8.800 .000 \\
\hline & Total penerimaan satu periode & & & 297.550 .000 \\
\hline
\end{tabular}




\begin{tabular}{|c|c|c|c|c|}
\hline No. & Items & Volume & Price (IDR) & Total (IDR) \\
\hline C. & Net income & & & \\
\hline & Income in one period ( 3 years) & \multicolumn{3}{|c|}{$297.550 .000-206.540 .000=91.010 .000$} \\
\hline D. & R/C Ratio & \multicolumn{3}{|c|}{$297.550 .000: 206.540 .000=1,44$} \\
\hline
\end{tabular}

In general, the farmers are price taker, especially for the transaction types of debt bondage/farmer loan transactions from collectors. In this condition, the bargaining power of the farmers is very low, so that the farmers do not have the opportunity to determine the selling price. The dominant transaction type is a transaction made by the buyer before the harvest period ("yarnen"). Farmers have relatively good bargaining power if they have good yields and do not have loans to middlemen/collectors. The type of regular transaction in which farmers after harvesting can sell to collectors. Farmers can compare the selling price with other farmers, so that they are free to determine the buyer who provides a higher selling price. The value of $\mathrm{R} / \mathrm{C}$ for the total cost as much as 1,44 means that each $\mathrm{Rp}$

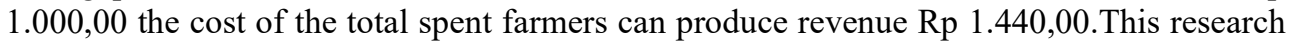
in line with the research [12] showing farming enterprises pineapple considered to be profitable by the value of $\mathrm{R} / \mathrm{C}$ for the total cost as much as 1,58 , value $\mathrm{R} / \mathrm{C}$ on farming land being is nenas 2,26 and 1,81 for narrow land [13]

The dependence of farmers on collectors due to the lack access of farmers to formal bank. Collectors also have the ability to access traders in the wholesale market as well as capital to support marketing.

Farmer Institution. In Punggur Subdistrict had a Farmer-Owned Enterprise (BUMP) in 2014. BUMP collaborates with Village-owned Enterprise (Bumdes) which has partnered with retail, and profit-sharing is based on a profit-sharing scheme. With direction and input from the local government, in 2017 BUMP became a formal Company (PT) under the name PT Agro Nenas Cipta Sejahtera (PT. ANCS), which is owned by 8 farmer groups, with 400 members. Chairman of PT. ANCS initially played an active role in promoting Punggur pineapple to the provincial level and also to Jakarta by participating in various exhibition events. Furthermore, trying to find a new breakthrough by looking for buyer partners.

There are several partners, who want to join the farmers, both entrepreneurs from Dubai and Australia, as well as Agro Outlet from Jakarta. They need a continues supply from the farmers, and buy fresh pineapples on real time prices. They need around 2,000 - 3,000 pieces every week. Agro Outlet will provide prices above the collecting traders. The farmers have difficulty to fulfil this supply, especially due to low rainfall (dry) in July November, so that pineapple production is disrupted. In the last two years, PT ANCS did not run normally, the chair did not focus on managing the company due to running to be a member of provincial legislative. The farmers no longer sell their crops to PT ANCS, and most of them sell directly to collectors. The farmers hope that the company can return to business as usual.

Several groups of women farmers (KWT) in Punggur Subdistrict have tried to diversify pineapple processing into several processed products such as: pineapple chips, pineapple lunkhead and pineapple syrup. The raw material used is pineapples which are rejected for sale. KWT has received assistance from the government for a vacuum fryer and uses it to make pineapple chips. The main problem for the KWT initiative, they have difficulty to sale the product. Besides, the price of pineapple chips is relatively expensive and only certain people buy it. Other preparations such as pineapple lunkhead have been made, and the remaining peeled skin is extracted to make pineapple syrup. KWT will make processed products if they get an order.

Pineapple Development Constraints. The main problems and obstacles in pineapple development in Punggur District, among others:

1) Limited access to the water especially in a long dry season in July - November.

2) Limited land processing equipment (tractors) 
3) Lack access to formal bank, and most of them depend on neighbours and middlemen

4) The emergence of red shoot pests on pineapple leaves. This pest emerged 2 years ago, disrupted $50 \%$ of production, and downgraded from grade $\mathrm{A}$ to $\mathrm{B}$ or $\mathrm{C}$.

5) The bargaining position of the farmers in marketing the products is relatively low. PT. ANCS (BUMP) still have problem with management.

6) Strengthening the Women Farmers Group (KWT) need guidance in processing process to increase the quality of product, as well as marketing diversified products.

\subsection{SWOT analysis and strategy of pinneaple industry development in Central Lampung Regency}

The results of the SWOT analysis show that there are four strengths, five weaknesses, five opportunities and three threats in the pinneaple industry in Lampung Tengah Regency. Table 5 shows that the strength factor with the highest score is experienced farmers in pineapple farming. Therefore, the experienced farmers is an important factor for the development of Lampung Tengah Regency to become a national pineapple production center. In addition, other influencing factors are pineapple farming as the main income for farmers, farmers being able to process pineapples into product diversification, and being independent in providing seeds.

The most influential weakness factor is the decline in the management performance of PT. ANCS belongs to 8 farmer groups, especially in marketing pineapples. This causes farmers to sell their pineapple products by themselves so that they are very dependent on collecting traders which results in a weak bargaining position for farmers. Efforts to expand the market have actually been carried out with an offer to purchase pineapples continuously by a company as much as 2,000 - 3,000 pineapples / week, but farmers are not able to fulfill due to low production capacity. Another weakness factor is the lack of land processing equipment, and the diversification of pineapple products made by farmers is still of low quality and expensive.

Table 5. Internal Factor Evaluation (IFE) Matrix

\begin{tabular}{|c|c|c|c|}
\hline Internal Factors & Weight & Rating (1-4) & Score \\
\hline \multicolumn{4}{|l|}{ Strengths } \\
\hline $\begin{array}{l}\text { 1. The Farmers have a long experience in pineapple } \\
\text { cultivation }\end{array}$ & 0,15 & 4 & 0,59 \\
\hline 2. Pineapple farming is the main income for the farmers & 0,15 & 3 & 0,46 \\
\hline $\begin{array}{l}\text { 3. Farmers are able to process pineapples into product } \\
\text { diversification }\end{array}$ & 0,08 & 2 & 0,16 \\
\hline 4. There are pineapple seed providers & 0,12 & 3 & 0,35 \\
\hline Sub Total Strengths & & & 1,57 \\
\hline \multicolumn{4}{|l|}{ Weaknesses } \\
\hline 1. Lack of tillage equipment & 0.118 & 3 & 0,32 \\
\hline $\begin{array}{l}\text { 2. Bargaining position of farmers in pineapple } \\
\text { marketing is low }\end{array}$ & 0.112 & 4 & 0,41 \\
\hline $\begin{array}{l}\text { 3. The management of PT ANCS. which belongs to } 8 \\
\text { poktan. is weak in marketing its pineapples }\end{array}$ & 0.124 & 4 & 0,45 \\
\hline $\begin{array}{l}\text { 4. Farmers are not able to meet the demand in large } \\
\text { quantities }(2000-3000 \mathrm{~kg} / \text { week) continuously }\end{array}$ & 0.101 & 2 & 0,18 \\
\hline $\begin{array}{l}\text { 5. The diversified pineapple products made by farmers } \\
\text { are low quality and expensive }\end{array}$ & 0.062 & 1 & 0,08 \\
\hline Sub Total Weaknesses & & & 1,45 \\
\hline TOTAL & 1.0 & & 3,02 \\
\hline
\end{tabular}


The opportunities from external environment in pinneaple Industry in Central Lampung Regency can be used to support the development of pinneaple industry. The most influencing opportunity factor is the establishment of PT. ANCS by 8 farmer groups to market pineapple products. Even though currently the performance of the management is very low, but improving the company's management and developing its business will increase the income of pineapple farmers. In addition, there are farmers who have received Prima 2 certificates for their pineapple farming, which means that their pineapple products are guaranteed to be good and safe for consumption, and an increase in consumer awareness of the quality and safety of fresh pineapple products are opportunities that can be utilized for the development of the pineapple industry. Other opportunities are the pineapple marketing chain has been formed, there is a demand for $2,000-3,000 \mathrm{~kg}$ of pineapple per week whose price is above the collector's price, and there is already a small pineapple processing business (Table 6). But, the industry has also to address threathies from external environment, those are the emergence of red shoot pests on pineapple leaves, followed by in the dry season the growth of pineapples is disrupted due to lack of water and there is no financial institution that is easily accessible to farmers.

Table 6. External Factor Evaluation (EFE) Matrix

\begin{tabular}{|c|c|c|c|}
\hline External Factors & Weight & Rating (1-4) & Score \\
\hline \multicolumn{4}{|l|}{ Opportunity } \\
\hline $\begin{array}{l}\text { 1. There have been farmers who have received a Prima } 2 \\
\text { certificate }\end{array}$ & 0,11 & 3 & 0,32 \\
\hline $\begin{array}{l}\text { 2. Consumers awareness of quality and safe fresh pineapple } \\
\text { products is increasing }\end{array}$ & 0,12 & 3 & 0,36 \\
\hline 3. Pineapple marketing Chain has formed & 0,13 & 2 & 0,26 \\
\hline $\begin{array}{l}\text { 4. Eight farmer groups have formed PT ANCS to market } \\
\text { pineapples }\end{array}$ & 0,12 & 4 & 0,48 \\
\hline $\begin{array}{l}\text { 5. There is a demand for } 2000-3000 \mathrm{~kg} \text { of pineapples per } \\
\text { week at prices above the collector's Prince }\end{array}$ & 0,10 & 3 & 0,29 \\
\hline 6. There are already small pineapple processing businesses & 0,05 & 4 & 0,22 \\
\hline Sub Total Opportunity & & & 1,94 \\
\hline \multicolumn{4}{|l|}{ Threath } \\
\hline $\begin{array}{l}\text { 1. In the dry season pineapple growth is disrupted due to } \\
\text { lack of water }\end{array}$ & 0,12 & 3 & 0,35 \\
\hline 2. The emergence of red shoot pests on pineapple leaves & 0,15 & 4 & 0,58 \\
\hline $\begin{array}{l}\text { 3. There are no financial institutions that are easily } \\
\text { accessible to farmers }\end{array}$ & 0,10 & 3 & 0,30 \\
\hline Sub Total Threath & & & 1,23 \\
\hline Total EFE & 1.0 & & 3,18 \\
\hline
\end{tabular}

Based on Internal Factors Evaluation (IFE) - External Factor Evaluation (EFE) analysis with a coefficient of in accordance to those performed by Ermayani, Hubeis \& Sarma (2010) dan Ommani (2010), IFE score $(3,02)$ is lower than EFE $(3,18)$, this mean that the industry prioritize external factors than internal factors (Figure 1). To determine what strategy the Industry should undertake, the IFE - EFE scores are put in the Strategic Position and Action Evaluation (SPACE) matrix. The result shows that the strategy should take is Development (SO) Strategy, meaning that the industry optimize the strengths to make the most of opportunities as optimally as possible. 


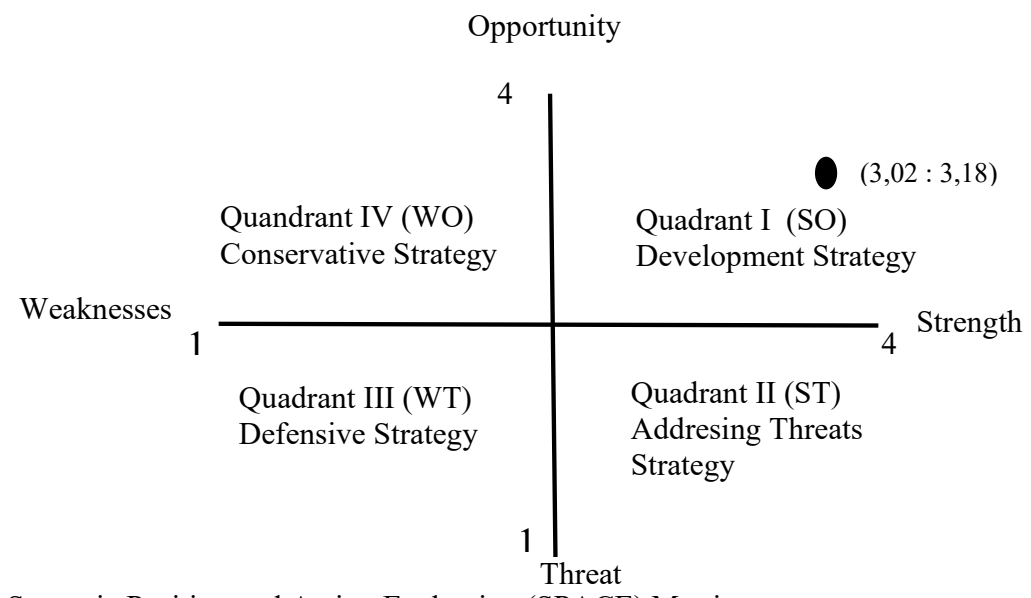

Fig 1. Strategic Position and Action Evaluation (SPACE) Matrix

Steps that need to be taken as the implementation of the pineapple industry development strategy based on farmer corporations in Central Lampung Regency can be divided into two parts: First, Increasing the quantity and quality of production through: (a) Increasing the adequacy of water for pineapple cultivation, especially during the dry season (July November). Assistance in making deep wells, reservoirs and equipment in the form of suction pumps at several points in pineapple cultivation locations; (b) Acceleration of land processing, by adding tools/machines in the form of hand tractors to facilitate land plowing and ditching; and (c) Improvements in cultivation, including control of plant pests and diseases,especially wilt caused by a virus (Closterovirus) called Pineapple mealybug wiltassociated viruses (PMWaV) or also known as live virus associated with mealybugs (Dysmycoccus brevises); and Second, Institutional strengthening of Farmer Corporations through: (a) Establish partnerships with financial institutions such as KUR to meet farming capital needs; (b) Improve the performance of the management of PT. ANCS is actively seeking market opportunities and establishing pineapple marketing partnerships, providing inputs for pineapple farming production, as well as cooperating with SOEs and other stakeholders; (c) Improved KWT skills in making pineapple processed products and marketing processed pineapple products including online marketing through training and mentoring by the government and other institutions such as TDA and Genpro; (d) Capacity building of farmers in pineapple farming technology through participatory training and demonstration; and (e) Increasing the competence of field extension workers through intensive training using information technology.

\section{Conclusion}

The results of the analysis of financial feasibility indicates that the pinapple corporate farming in Kecamatan Punggur Lampung Tengah District is financially feasible. Based on the analysis that the power factor becomes the most influential internal factor, besides its also has the opportunity to be the most influential external factors in the development of pineapple-based corporate farming Kabupaten Lampung Tengah. Therefore, the main strategy in the development of pineapple-based corporate farming in Central Lampung Regency is emphasized on how to use the power and catch the available opportunities. Some alternative policy recommendations that can be applied are improving the production and maintaining the quality of products, improving the performance of the institutional and corporate farming growth, as well as developing the qualified 
diversification product. Another policy recommendation that can be aplied as a supporter of the development of the pineapple in Central Lampung Regency is an increasing in the role and skills of trainers; and farmer groups or corporates in proceesing and marketing pineapple.

\section{References}

1. A. T. Basuki, J. Ekon. Studi Pembang. 13, 1, 53-71 (2012)

2. BPS-Statictics Indonesia, Statistical Yearbook of Indonesia 2019 (BPS-Statictics Indonesia, Jakarta, 2020)

3. S.E. Utomo, Analisis Perbandingan Potensi Ekonomi Kabupaten Dan Kota Di Provinsi Lampung [Thesis] (Fakultas Ekonomi dan Bisnis, Universitas Muhammadiyah Malang, 2014)

4. I. Martadona, Y.L. Purnamadewi, M. Najib, Tataloka 16, 4, 234-244 (2014)

5. Pusdatin, Agricultural statistics 2016 (Pusdatin, Indonesian Ministry of Agriculture, Jakarta, 2016)

6. D. Herdhiansyah, L. Sutiarso, D. Purwadi, J. Tek. Ind. 13, 2, 201-209 (2012)

7. D. Ermayani, A.V.S. Hubeis, M. Sarma, J. Manag. Pengemb. Ind. Kecil Menengah 5, 1, 53-64 (2010)

8. Kementan, Rencana Strategis Kementerian Pertanian 2020-2024 (Kementan, Jakarta, 2020)

9. A.R. Ommani, Afr. J. of Bus. Manag. 5, 22, 9448-9454 (2011)

10. E. Gürel, M. Tat, J. Int. Soc. Res. 10, 51, 6-11 (2017)

11. S. Anggraini, Analisis pengaruh sektor pertanian dan sektor Industri pengolahan terhadap pertumbuhan ekonomi Kabupaten lampung tengah periode 2011-2017 Dalam Perspektif Ekonomi Islam [Skripsi] (Fak. Ekonomi dan Bisnis Islam UIN Raden Intan Lampung, Lampung, 2019)

12. A.K.Wardani, Analisis Usahatani Nanas Pada Kelompok Tani Makmur Desa Astomulyo, Kecamatan Punggur, Lampung Tengah [Skripsi] (Departemen Agribisnis Fakultas Ekonomi Dan Manajemen Institut Pertanian Bogor, Bogor, 2012)

13. BPS-Statistics of Lampung Tengah Regency, Lampung Tengah Regencies in Figures 2021 (BPS-Statistics of Lampung Tengah, 2021) 